\title{
THE VIEW FROM EVERYWHERE: DISCIPLINING DIVERSITY IN POST-WORLD WAR II INTERNATIONAL SOCIAL SCIENCE
}

\author{
PERRIN SELCER
}

\begin{abstract}
This paper explores the attempt of social scientists associated with Unesco to create a system of knowledge production to provide the international perspective necessary for democratic governance of a world community. Social scientists constructed a federal system of international associations that institutionalized American disciplines on an international scale. An international perspective emerged through the process of interdisciplinary international research. I call this ideal of coordinating multiple subjectivities to produce objectivity the "view from everywhere." Influenced by social psychological "action-research," collaborative research was group therapy. The attempt to operationalize internationalists' rallying slogan, "unity in diversity," illuminated tensions inherent in the mobilization of science for social and political reform. (C) 2009 Wiley Periodicals, Inc.
\end{abstract}

... freedom is really another word for subjectivity, and there comes a day when it can no longer stand itself, despairs at some point of the possibility of being creative on its own, and seeks protection and security in objectivity. Freedom always has a propensity for dialectic reversal. It very quickly recognizes itself in restraint, finds fulfillment in subordinating itself to law, rule, coercion, system - finds fulfillment in them, but that does not mean it ceases to be freedom.

Doctor Faustus (Mann, 1997, p. 203)

In the late 1940s and early 1950s, experts associated with the Social Sciences Department of the United Nations Educational, Scientific and Cultural Organization (Unesco) consciously sought to create a scientific way of knowing that would bring unity to diversity. This project depended on a novel system of international disciplinary associations modeled on the American Social Science Research Council. Like the SSRC, the new system idealized interdisciplinarity; however, whether they were political scientists like Walter Sharp, sociologists like Stein Rokkan, or self-identified social psychologists like Otto Klineberg, most of its key architects shared the common mid-century affinity for the theories and practices of social psychology. ${ }^{1}$ The new international associations were intended to equitably share the power of technical knowledge to improve social welfare and to create transnational affiliations that cultivated loyalty to an emergent world community. The social scientists also saw them as a means

1. Mid-century social psychology was a cannibalistic discipline best understood broadly. Culture and personality research; survey research, community studies, and opinion polling; psychiatry; the avant-garde of political science and public administration - all of these fields interacted to produce social psychology. In this sense, disciplinary histories of social psychology are misleading. For the research described in this paper, Kurt Lewin's work was particularly important, and no single organization more influenced the SSD in its early years than the Society for the Psychological Study of Social Issues (SPSSI). On Lewin, see Ash (1992); for the German roots of Gestalt theory, Ash (1995). On the SPSSI, see Harris and Nicholson (1998); Murphy (1945). More broadly, see Herman (1995). Beyond histories of psychology, see Converse (1987); Stocking (1986).

PERRIN SELCER is completing his dissertation, "Patterns of Science: Developing Knowledge for a World Community, Unesco 1946-1973," in the History and Sociology of Science Department of the University of Pennsylvania. His article "Standardizing Wounds: Alexis Carrel and the Scientific Management of Life in the First World War" appeared in the British Journal for the History of Science in 2007. In 2008, he was awarded the John C. Burnham Early Career Award from the Forum for the History of the Human Sciences. Currently, he is a Visiting Scholar in the Science, Technology, and Public Policy program at the University of Michigan. 
of determining truth in the international community, a particularly difficult problem in the realm of social knowledge. In the international associations, scholars would represent national perspectives but share a common technical language. By coordinating these diverse yet disciplined perspectives in interdisciplinary projects, the Social Sciences Department (SSD) hoped to produce what I call a "view from everywhere."

In an important sense, the view from everywhere resembled the God's-eye "view from nowhere" that the natural sciences attempted to manufacture (Nagel, 1986). Like the view from nowhere, it was an impossible ideal that sought to transcend partial perspective. Yet while detachment from particular values characterized the view from nowhere, the view from everywhere depended on deep engagement with particular values. International social science was, and was intended to be, value laden. And while the view from nowhere promoted a universal scientific perspective, the view from everywhere claimed to represent diverse national points of view. It was, after all, embedded in an international political order that idealized inclusive representation. As Lorraine Daston and Peter Galison observe, "Objectivity is always defined by its more robust and threatening complement, subjectivity" (Daston \& Galison, 2007, p. 258); but in this strategy, the challenge of multiple subjectivities was an opportunity to achieve a more perfect objectivity. Coordinating the view from everywhere was an attempt to operationalize the core value of the advocates of world community: unity in diversity. ${ }^{2}$

Soliciting diverse perspectives proved easier than synthesizing them into a unity. As agents of the international community, the experts and civil servants who worked for intergovernmental organizations aspired to represent an international perspective, but each was still a product of a particular cultural pattern. Guided by the burgeoning field of human relations, especially Kurt Lewin's work on group dynamics, internationalist social scientists attempted to manage the tension between diversity and unity through action-research that simultaneously discovered and produced the conditions in which cooperative interpersonal relations thrived. In this therapeutic approach to social reform, intersubjective acuity was as important as statistical acumen; objectivity merged with empathy (on intersubjectivity, see Carson, 2003).

This paper engages with prominent themes in the historiography of postwar U.S. social science, but approaches them from the perspective of the archive of an international governmental organization (IGO) headquartered in Paris. The SSD's goal of cultivating an international community of cosmopolitan social scientists was a version of the mid-twentieth-century conviction that the rational scientist was an exemplar of the democratic citizen and that the scientific community manifested in microcosm the appropriate norms of a democratic polity (Hollinger, 1995b; Cohen-Cole, 2004; Mendelsohn, 1989). Yet before scientists could offer themselves as models for world citizens, they had to shed their own nationalist blinders. Unesco's reliance on the tools of social psychology to construct (as the agency's constitution put it) "the defences of peace" in "the minds of men" was an international example of what Ellen Herman has described as the infusion of psychological rationality into the political culture of the postwar United States (Herman, 1995; Nolan, 1998). The notion of a "therapeutic state" can carry antidemocratic connotations, and by the mid-1950s, the sort of interdisciplinary social psychology promoted by Unesco was likely to be classified under the behavioral sciences or incorporated into modernization theory, fields that have earned invidious reputations

2. For historical and sociological studies of social strategies for determining truth, see Daston (1992); Megill (1994); Shapin (1994). My analysis also draws on work by sociologically inclined international relations scholars on transnational networks, truth, and values (Keck \& Skikkink, 1998) and on epistemic communities (Haas, 1992). For a recent call for an intellectual program that in many ways resembles (self-consciously) the one described in this essay, see Hollinger (1995a). 
as quintessential Cold War social sciences. But as David Engerman recently observed, experts also deployed these forms of social knowledge in attempts to soften America's overwhelming military and economic power (Engerman, 2007). Although featuring many of the same characters, this story of American social scientists' attempts to intervene in the development of the international community is very different from the standard narrative that describes them as servants of American power. The project to construct a view from everywhere may not have appealed to U.S. foreign policy elites as much as the reductive universalism of the "mandarins of the future," but it certainly engaged the imaginations of many of the generation's best and brightest (Gilman, 2003; Lemov, 2005; Robin, 2001). U.S. social scientists who participated in Unesco's program in the late 1940s and early 1950s often intended to remake the world in an American image; but they were convinced, like their overseas colleagues, that a healthy world community also depended on reforming American culture.

The story of the United States' participation in Unesco's founding and early years has been well told as an example of the change in U.S. cultural relations policy at the beginning of the Cold War; a shift from an idealistic policy of ideological reconciliation through nongovernmental cultural exchange to a "realpolitik" that sought to maximize Unesco's propaganda potential for the free world (Graham, 2006; Ninkovitch, 1981). By focusing on the civil servants and experts who chose to work for the international organization (instead of national politicians and government officials) and on the social theory that underlay cultural relations (instead of national security communications), I demonstrate greater continuity in the evolution of Unesco's program and philosophy. More importantly, social scientists' commitment to international organizations reveals more complex interactions between intellectuals and their patrons than pipers singing their paymasters' praises (Saunders, 1999). World politics profoundly shaped the practice of international social science, but I take seriously these social scientists' radical ambition to use cultural knowledge to transform world politics. Their therapy was supposed to improve states, too.

This paper begins by describing the creation of a network of international associations designed to reform European social science and integrate the North Atlantic intellectual community. Next, it explores the shift to internationalization as a component of technical assistance to underdeveloped nations and the challenge this posed to the universality of social science. Finally, it analyzes the practice of action-research to reveal the cultural values and personality traits international organizations were supposed to cultivate. For the experts and civil servants who engaged in Unesco's program in the postwar period, overcoming the world crises of the twentieth century required a new way of knowing grounded in new institutions. Their attempt to discipline diversity in order to provide the objective knowledge necessary for an integrated world community illuminates tensions inherent in the mobilization of science for social and political reform.

\section{Institutionalizing North Atlantic Social Science}

When the United Nations system was founded, the inequitable international distribution of power was an obvious obstacle to democratic world government. Postwar internationalists believed that the anarchic disorganization of the young world society led to war; in the final analysis, peaceful progress only could be achieved with a world state. In the short term, however, the potential of a world state was a threat more than a goal. The Soviet Union's explicit objective was world communism, but for many internationalists, including Americans, the combination of U.S. military and economic strength, ignorance of foreign cultures, and immaturity in international affairs constituted a more realistic threat than 
international communism. ${ }^{3}$ The free world's fight against fascism helped legitimize the American federal system of liberal democracy as a model for a future world polity. Yet because the United States was the only major power to emerge materially stronger from World War II, it threatened to fill a global power vacuum. The concentration of political and economic power in the United States was paralleled in the intellectual sphere, where the influx of European refugee intellectuals, the sheer scale of the university system, and unmatched financial resources could easily make scientific internationalization look more like Americanization. The United States thus presented internationalists with a paradox: It was at once a model for the international community and a threat to it. The view from everywhere was, in part, a result of social scientists' confrontation with this paradox.

Social scientists' determination to resolve this paradox through international organizations must be understood in the context of the explosive growth of international institutions. Within a few years of its establishment, a bewildering number of specialized agencies had affiliated with the U.N. through formal agreements with the Economic and Social Council (ECOSOC): the International Labor Organization (ILO), Food and Agriculture Organization (FAO), World Health Organization (WHO), Unesco, Economic Commissions for Europe, Asia and the Far East, and Latin America (ECE, ECAFE, ECLA), International Civil Aviation Organization (ICAO), International Telecommunication Union (ITU), World Meteorological Organization (WMO), International Refugee Organization (IRO), and Universal Postal Union (UPU). Many of these agencies had precedents (e.g., for Unesco, the International Institute for Intellectual Cooperation) or were survivors (e.g., the ILO) from the interwar period or even earlier (e.g., the ITU). In addition, an assortment of reconstruction and regional IGOs and a bumper crop of international nongovernmental organizations (INGOs) joined the expanding international sphere. ${ }^{4}$ Internationalists hoped this new system would prove to be the embryo of an effective international government; internationalist social scientists believed an international government would require internationally produced social knowledge.

Unfortunately, the proliferation of new international organizations threatened to turn the international community into an illegible alphabet soup of acronyms, thus making a mockery of the dream of transforming the anarchic wilderness of states into an efficient world community. In 1947, American political scientist Walter Sharp expressed the anxiety of many experts over the "perfect 'rash' of meetings" (3,000 annually for the strictly U.N. organizations alone) that swamped international civil servants and experts. "What has been happening, from the institutional point-of-view," Sharp wrote, "is a largely unsystematic sprouting of machinery, multi-level and highly complicated as to structure. While this may be taken as an indication of vigorous initiative in an effort to re-organize the shattered war-torn world on some sort of cooperative basis, the loose and decentralized character of the emerging 'system' inevitably produces "wheels within wheels"' (Sharp, 1947, p. 472). Many experts, including U.N. Secretary-General Trygve Lie, called for a moratorium on new international agencies.

3. The USSR did not join Unesco until after Stalin's death. Poland, Czechoslovakia, and Hungary were members of Unesco, but during the period of this study they were boycotting the organization. While cold war anxieties energized social scientists work, the absence of the East Bloc meant that their negotiations over the institutions and norms of international social science revealed tensions that were in important respects independent of the cold war. In the last decade, the need to look beyond the cold war to develop a more complete explanation of postwar international relations has been widely recognized. For an early statement, see Connelly (2000). For the distinction between two postwar settlements, one manifested in liberal international institutions and the other in the policy of containment, see Ikenberry (2001). The best general political study of Unesco is Sewell (1975).

4. Akira Iriye cites the number of IGOs increasing between 1940 and 1950 from 38 to 81, and INGOs from 477 to 795 , although he points out that the numbers vary depending on who is counting (2002, p. 55). The International Bank for Reconstruction and Development and the International Monetary Fund were also considered specialized agencies of the U.N., although in practice they participated in the U.N. system quite differently. 
Unesco was the most energetic catalyst of new international organizations. Public administration expert Charles Ascher quoted a member of the Arts and Letters staff: "We looked over the international field in the arts and saw that there was a gap - no international organization in the theatre; so we decided that there ought to be one" (Ascher, 1951, p. 18). In 1947, Unesco had already granted consultative status to 69 INGOs and contracted work to 30 organizations. By 1954, 125 organizations held consultative status with Unesco, 58 signed contracts, and Unesco was represented at 130 meetings convened by INGOs. In 1950, the Secretariat bragged that not even the Economic and Social Council, let alone other specialized agencies, had as many INGO affiliates (Unesco, 1950a). The logic worked like this: Unesco would set up INGOs in the areas of education, science, and culture that would then provide Unesco expert advice and to which it would contract out much of its program. Outsourcing research to INGOs was particularly important to the SSD because it was difficult for an IGO to assert anything significant about society without alienating some member state.

In addition, the new INGOs intrinsically accomplished one of Unesco's chief missions, creating transnational communities. In the words of Director-General Jaime Torres Bodet, "The development of this world network of institutions and associations specializing in the various branches of intellectual co-operation is, for Unesco, both an end and a means" (Unesco, 1950a, p. 17). For the intellectuals who participated in the transnational associations, the institutional development of Unesco also was both an end and a means. The boundaries between institutional types in the international sphere were porous. Experts moved between IGOs, INGOs, universities, foundations, state bureaucracies, and semi-governmental organizations. Indeed, a sort of osmotic theory of reform was one way international organizations promised to spread norms appropriate for a world community. ${ }^{5}$

For the first director of the Natural Sciences Department, renewing and expanding the network of international scientific unions disrupted by the war was certainly an end in itself. The British biochemist Joseph Needham had spent the war years directing the Sino-British Science Co-operation Office in Chongqing, and joined Unesco in large part to help strengthen science in "the periphery." During his brief tenure, Unesco became virtually the sole patron of the reconstituted International Council of Scientific Unions (ICSU). ICSU (like many international acronyms, pronounced as a word: ick-sue), founded in 1919 as the International Research Council, was a federation of international scientific unions, which were in turn a federation of national associations (Greenway, 1996; Petijean, 2006). Needham not only advocated Unesco sponsorship of ICSU, he also coordinated the formation of new unions. ${ }^{6}$ In the ideal model, in return for its subventions, Unesco would request research from ICSU, which would farm out the work through the appropriate disciplinary unions, which in turn would draw on their national member associations. The metaphor that guided the reconstitution of ICSU was the gear works of a clock, not Sharp's "wheels within wheels."

Both the Cultural Activities Department and the SSD followed the Natural Sciences' lead. In 1947, the General Conference resolved to "encourage" setting up an International Council for Philosophy and Humanistic Studies "similar to the International Council of Scientific Unions," and the ICPHS was incorporated in Brussels in 1949 as a federation of six

5. For other examples of the porous boundaries between the governmental and nongovernmental spheres, see Connelly (2006) and Goldman (2007). These authors emphasize the unaccountable, unrepresentative power of networks of transnational policy elites. For more positive analyses of the potential of transnational interorganizational collaboration, see Keck and Skikkink (1998), and Khagram (2004).

6. In a typical move, he advised scientists organizing an International Society for Cell Biology to affiliate through ICSU's International Union of Biological Sciences, which it ultimately did, since "U.N.E.S.C.O. [had] undertaken to provide certain financial and other facilities ... to those international societies which are affiliated to the [ICSU]" (Memo from Honor Fell, 1947, 576.3 A 01 ISCB, International Society for Cell Biology, Unesco correspondence). 
international scholarly organizations (Unesco, 1948a; Fawtier, 1949, p. 2). Social scientists, ever conscious of insidious lags, were eager to catch up to both the natural sciences and humanities in international organization; they did not even have any international disciplinary associations to federate. ${ }^{7}$ The SSD itself suffered from disorganization due to lack of steady leadership until the dynamic Swede Alva Myrdal (Gunnar's wife) moved from the U.N.'s Economic and Social Council in New York to Paris to take over the department in 1950. Still, with its administration largely handled by a rotating series of American academics-Walter Sharp, then at CUNY; the University of Michigan sociologist Robert C. Angell; and the peripatetic, Columbia University-affiliated social psychologist Otto Klinberg - the SSD set about "stimulating" the creation of the missing international associations. By the end of 1949, the IEA (International Economic Association), ISA (Sociology), IPSA (Political Science), and ICLA (Comparative Law) had joined the alphabet soup under Unesco auspices, and each was provided a $\$ 3,000$ annual subvention. ${ }^{8}$ In October 1952, the International Union of Scientific Psychology joined these four associations to convene the Provisional International Social Science Council (ISSC), which ideally would collaborate closely with the Humanities Council "since it is impossible to draw a strict borderline between the Social and Humanistic Sciences" (ISSC, 1954). ${ }^{9}$ Like the International Council of Scientific Unions, the ISSC was given an office in Unesco House. This new institutional structure was the framework on which the view from everywhere would be constructed.

It was a fragile framework. The first issue of Unesco's International Social Science Bulletin identified the major weakness (one the journal itself was meant to overcome): "It rapidly became evident that the very expression 'social science' meant widely different things in different countries or, if [social science disciplines] did exist, had significance and content totally different from that attributed to them elsewhere" (Anon., 1949a, p. 9). For many European intellectuals, the "social sciences" belonged with the humanities, and social knowledge should not be arbitrarily divided between, for example, politics and economics. ${ }^{10}$ Furthermore, Americans' obsession with empirical validity merely resulted in the pointless accumulation of data. Nevertheless, the social sciences were organized as a separate division in Unesco following an American vision that looked to the natural sciences as an epistemological and institutional model.

The flurry of activity in the late 1940s institutionalized the disciplinary structure of U.S. social science in the international community. The International Comparative Law Association acknowledged the Latin emphasis on juristic studies rather than the American notion of political science, but the ISSC was explicitly modeled on the U.S. Social Science Research Council. In the SSRC, social knowledge was differentiated into specialties that corresponded to university departments, but then the disciplines were integrated through interdisciplinary research projects. The goal was to produce empirically validated useful knowledge that enhanced

\footnotetext{
7. A Unesco study of seventeen international organizations in the social sciences identified eight that had been formed before 1945 (three in the nineteenth century and five between the wars), but these were narrower and more applied than the disciplinary associations (e.g., criminology, administrative sciences, and econometrics) or more explicitly reform oriented (e.g., the International Law Association, which lobbied for the codification of international law). The International Studies Conference (not included in the survey) was a preexisting international association founded between the wars through the International Institute for Intellectual Cooperation, but social scientists disagreed over whether it corresponded to a discipline. Psychologists were better organized internationally, but not yet as social psychologists (Meynaud, 1956).

8. Both the IPSA and ISA have commissioned useful histories; see Coakley and Trent (2000), and Platt (1998).

9. Exemplifying the ambiguity between the humanities and social sciences, the International Union of Anthropological and Ethnological Sciences already had joined the Humanities Council. A somewhat awkward proposal to join the ISSC had to be extended to this previously engaged union, which was ironic given that Claude LéviStrauss was the secretary-general of the ISSC.

10. For a useful discussion of these points focusing on political science, see Unesco (1950b).
} 
methodological and theoretical sophistication (Worcester, 2001). The influence of American social scientists is nicely symbolized by the first presidents of the ISA, IPSA, and IEA: friends and colleagues at the University of Chicago Louis Wirth (sociology) and Quincy Wright (political science), and Gottfried Haberler of Harvard (economics). That Wirth was born in Germany and Haberler a native Austrian is equally illustrative. One reason American social science was acceptable as a Transatlantic standard was that its development had been decisively shaped by Europeans, particularly Germans, whose Continental influence before Nazism also had been profound.

Indeed, some European social scientists enthusiastically endorsed American social scientific norms. A memo speculating on the possibility of an international conference on the "role of scientists in world affairs" expressed a commonplace of the SSD: "In Europe the social scientists have a tradition very different from the one in the [United] States. More than is generally realized, they have to be convinced of the possibility of really using the social sciences as a tool" (Memo from den Hollander, 3 October 1950, 327.63 A 06, Meeting of Social Scientists on "The Role of Social Scientists in World Affairs," Unesco correspondence). This was written by a Dutch sociologist. After spending much of the 1930s and the war in the States, many European scholars embraced an American social science that they had helped create (Krohn, 1993; Coser, 1984). Max Horkheimer, back in Germany after having relocated the Frankfurt Institute to New York and California during Nazi rule, hoped the SSD could "dispel part of the emotional clouds, which in Europe usually surround social and political problems," and asserted that the "keen insight into the life-processes of modern society" necessary for democracy "can be fomented only, if sociology becomes in Europe, what it has become in America for a long time: the substantial part of every curriculum of higher learning, particularly at the universities" (Horkheimer to Angell, 24 March 1950, 327.63 A 06, Meeting of Social Scientists on "The Role of Social Scientists in World Affairs," Unesco correspondence). Social scientists tended to agree on the differences between American and European social science, but nationality did not determine which style one preferred.

For the most part, however, it was not Europeans who initiated the formation of the international associations - it was Americans. A letter from Robert C. Angell, temporarily serving as head of the SSD's Tensions Project, to the President of the SSRC, Pendleton Herring, sheds light on the dilemma this posed. The SSRC was the official liaison to the SSD; it was charged with referring American experts to Unesco, coordinating SSD activities in the United States, and providing advice to the SSD. Angell wrote to "Pen" about his colleague at Unesco Otto Klineberg's efforts to organize an international association for social psychology—a key postwar objective of the U.S. Society for the Psychological Study of Social Issues, of which Klineberg was a past-president:

There are already three organizations that are pretty close to this one in their interests. ... Furthermore, social psychologists are very heavily concentrated in the United States to the point that an international organization would be made up of, perhaps, three-fourths Americans. Finally, the pattern of Unesco-sponsored international groups is a federal one, and to date international organizations [sic - must mean national organizations] in the field of social psychology are almost non-existent. Otto has agreed to talk this matter over further with social psychologists at home, but I thought you might like to consider it in a broader perspective. (Angell to Herring, 17 November 1949, 327.5: 301 A 53, Tensions Affecting International Understanding-Community Studies, Part II, Unesco)

Already in 1949, concern was shifting from an absence of international associations to redundancy, U.S. dominance, and an international sphere in danger of collapsing due to a void 
at the national level. That Angell appealed to Herring at the SSRC to mediate this dilemma underscores the problem; in the ideal organizational chart of the international bureaucracy, the SSRC ranked below the SSD. But in reality, the SSRC was far better established and connected - to universities, foundations, and the U.S. government. ${ }^{11}$

What most dramatically differentiated American social science was not its constantly invoked empiricism (which was also seen as a British characteristic) or its instrumentality, but its institutional success. An International Sociological Association evaluation described Unesco's role as accelerating the institutionalization of the social sciences, a process most advanced in the United States with the "greater nations" of Europe lagging behind and essentially nonexistent elsewhere (ISA, 1953). ${ }^{12}$ The structure of American social science was less a product of the rational organization of knowledge than a result of the startling expansion of American higher education. In 1950, the United States was home to 1,800 colleges and universities with 2.6 million students. Despite its own postwar student boom, Great Britain had 85,000 students in eighteen universities. The combined number of teaching posts in sociology, social psychology, and social anthropology in Egypt, France, Great Britain, India, Mexico, Poland, and Sweden was 141. In the United States, a survey of the American Sociological Association revealed that " 74 percent of the 2,148 [members] whose occupation was known were teaching in 'colleges' or universities" (Unesco, 1954a, pp. 15-16; Unesco, 1953, p. 12). As Unesco's survey commented, the teaching of social sciences in the United States had "reached a scale beyond all comparison with that found in other countries" (de Bie et al., 1953, pp. 32-33). The continuing expansion of the U.S. university system, in which undergraduate education underwrote research careers, encouraged a degree of specialization unmatched elsewhere (Kohler, 1990). More than epistemological disputes, these differences of structure and scale obstructed the internationalization of social science.

While the American academic system quantitatively out-produced the European system, the Continental university structure effectively established intellectual stars and academic barons (Clark, 1973; Judt, 1992). In a working paper for the first meeting of international associations called to plan a survey of social science in higher education, the SSD singled out France and Italy as falling below the "Anglo-Saxon and Scandinavian" pedagogic standard. But after pointed comments from the meeting's chairman, French Secretary of the International Political Science Association Jean Meynaud, this comment was expunged from the published report. The well-established scholars, often holding coveted chairs, who represented these countries showed little inclination to copy "Anglo-Saxon" blueprints for remodeling the structures in which they were quite comfortable (Unesco, 1950c; Anon., 1951a). ${ }^{13}$

Behind-the-scenes maneuvers over the nomination of delegates to the ISSC Executive Council illuminate how social scientists tried to limit yet capitalize on American power. The secretary of the International Sociological Association, Norwegian Stein Rokkan, wrote to Morris Ginsberg (London School of Economics) and George Davy (University of Paris), the vice presidents of the ISA charged with selecting delegates to the Council, urging them to select an American as president: "There can be very little doubt that the future of the proposed International Social Science Council will depend very much on the close co-operation with

11. For example, during this period a CIA representative attended SSRC meetings and the council was responsible for channeling foundation money into the social sciences (Worcester, 2001).

12. On the dramatic postwar switch from the perception that U.S. social knowledge lagged behind to the perception that it led, see Rodgers (1998).

13. Europeans did use the surveys to evaluate their standing in the social sciences and argue for particular reforms. For example, the Howard League for Penal Reform used a Unesco survey on criminology that showed Britain lagging behind the continent to pressure the Home Secretary for government support to establish an institute of criminology (London Times, 1957). 
the American SSRC, the Foundations and the active research centers and organizations in the United States." He endorsed Arvid Broderson, who was strategically placed in New York at the New School for Social Research and, as a former director of the SSD, already familiar with the machinery of international social science. To make the nomination palatable, he pointed out that Broderson, a Norwegian, could be seen as representing Scandinavia. He copied the letters to Alva Myrdal, the Director of the SSD, noting the "embarrassing position" this lobbying put him in and hoped she could apply more direct pressure (Rokkan to Ginsberg, 16 July 1952, and Rokkan to Myrdal, 16 July 1952, 3 A 198/III ISR, Rokkan, Unesco correspondence). American resources were both needed and resented by many of those participating in a putatively "world" organization. ${ }^{14}$

Precisely because U.S. scientists already had access to a strong national organizational apparatus tied to the big American philanthropies and universities, the international organizations were more important to Europeans. ${ }^{15}$ While Americans were presidents of international associations, this was largely a ceremonial office; the more operationally important position of secretary went to Europeans. That close to 80 percent of participants in the International Sociological Association's four World Congresses in the 1950s, all held in Western Europe, were European may understate American influence (consistently around 15 percent of attendees) but does reflect the general geographic bias of the international associations (Platt, 1998, p. 63).

As John Krige has argued in the context of postwar natural sciences, Americans "tried to reconfigure the European scientific landscape," but they only succeeded in enrolling "an enfeebled Europe ... in a hegemonic postwar American project" because it was "coproduced hegemony" (2006, pp. 3, 2, 9). Europeans selected and adapted components of the American social science model, a model that itself was a product of Transatlantic exchange. When the project to internationalize the social sciences followed U.N. technical assistance programs outside the West, the greater cultural diversity strained the discipline necessary to sustain the view from everywhere.

\section{DisCIPLINE AND DiVERSITY}

In addition to the potential of American imperialism, there were the actual European empires. Many internationalists defined the democratic political order of the U.N. through opposition to empires. With the first wave of decolonization in Asia, the advent of the U.N.'s Expanded Program of Technical Assistance, the beginning of economic recovery in Western Europe, and the intensification of the Cold War, (which undermined hopes of ideological reconciliation and added urgency to development programs), Unesco's locus of reform shifted from Europe to the "underdeveloped" nations of what soon would be labeled the Third World. The incorporation of non-Western nations into the international social science community posed critical but potentially enriching challenges to the viability of the view from everywhere.

Newly independent states joined U.N. organizations with alacrity because membership signified formal political equality; the idea of the U.N. as the antithesis of empire became

14. In the end, Donald Young, director of the Russell Sage Foundation, was elected ISSC president to fill the liaison role. Young as president and Lévi-Strauss as secretary-general perfectly illustrate the roles of Americans and Europeans in the international associations; an analogous situation existed in the ICSU. On the history of American-European intellectual relations, see Pells (1997), and Scott-Smith and Krabbendam (2003).

15. The time and expense of transatlantic travel (meetings usually were held at Unesco House) also limited American participation - especially when any work affiliated with an IGO required a notoriously inefficient background check to certify one's loyalty and integrity. As the case of the IPSA following suggests, the logistics of travel were even more limiting to Australians, South Americans, and Indians. 
reality. Yet while political structures underwent radical change, the developmental mission through which imperial powers had increasingly sought to legitimate colonial rule became the raison d'être of the U.N. specialized agencies (Jolly et al., 2004; Rist, 1997). Since economic development programs were experiments in planned social change that inevitably confronted political, cultural, and social factors, social scientists claimed that planning depended on comprehensive social knowledge. The advance of the social sciences in "underdeveloped" nations, therefore, was a prerequisite for democratic development; without experts, how could underdeveloped countries participate in rational planning? To distinguish their work from imperialism, the specialized agencies devised institutional structures that foregrounded inclusive democratic decision making. The democratization of science was an attempt to use knowledge to share power.

The problem of assuring balanced national representation was acute. Since they were intended to internationalize knowledge production, the legitimacy of the international associations rested on their national diversity. Even most European countries did not have disciplinary organizations in the social sciences, and so national associations and social science councils around the world "spontaneously" formed to participate in the new system. ${ }^{16}$ Organizers went to great lengths to assure geographic distribution. Myrdal insisted on keeping an Indian on the International Political Science Association Executive Council despite his inability to attend meetings (Robson to Myrdal, 24 November 1952, and Myrdal to Robson, 10 December 1952, 3 A 01 ISSC-66, International Social Science Council Part I (D), Unesco correspondence). As in the U.N., the legitimacy of the international associations rested on apparent equality of representation even when power was clearly not equally distributed.

The main activities of the international associations were holding world congresses, performing contract research for the SSD, developing dictionaries to define technical terminology, and managing clearinghouse services such as compiling bibliographies, abstracts, and international directories of experts (Unesco, 1956; Anon., 1951b, 1951c). The SSD's program in the internationalization of science worked closely with analogous programs in the other departments and was broadly representative of similar activities in other specialized agencies and major foundations. An SSD proposal to prepare "International Manuals in the Social Sciences" described the ultimate goal of this work: "Their principal value would be that, if widely used in universities ...., they would provide future representatives and negotiators from different countries with a common basis of facts and vocabulary, thereby immensely facilitating international understanding and agreement" ("Proposal for International Manuals in the Social Sciences," undated, 3 A 313, International Manuals in the Social Sciences, Unesco correspondence). Diplomats required common facts and figures, but for the professional experts who produced this knowledge, the bar was higher. The view from everywhere required the international practice of a common discipline, which depended on vibrant professional communities at the national level.

The first major research project of the international associations targeted the structural basis of social scientific inequality: a coordinated survey of university social science teaching in regionally representative or influential countries. These surveys provided the data necessary to guide educational reform in social scientifically "underdeveloped" countries toward the "proper curricula" of the "Anglo-Saxon and Scandinavian" countries (Unesco, 1950c). After the reports came in, twenty social scientists from eleven countries met at Unesco to formulate "proposals for the development and improvement of social science teaching."

16. The British Sociological Association was only the most prominent example of a widespread phenomenon (Platt, 2003). The SSD played an active role in these "spontaneous" formations; for example, see Unesco (1955). 
These included the "the creation of social science faculties composed of departments each covering a distinct branch of the sciences"; the inclusion of the social sciences in general education as part of training for citizenship; recommendations on qualifications for professorships and diplomas; and, "in view of the importance of value judgments in the field of social sciences[,] . . . 'a systematic study of value judgments and of the relations between questions of fact and questions of value" as a standard component of curricula (Anon., 1953, pp. 153-155). The project was an ideal type of SSD activity: The SSD coordinated the work of the international associations, which delegated to national members comprehensive, comparable surveys that led to recommendations for a standard set of reforms. In typical social science fashion, the reforms called for more social science. More important than the recommendations was the act of performing the surveys. For example, by cataloging the absence of teaching posts in social psychology in several countries, surveys reinforced the categories of a certain form of social science - for the first time, some states now lacked social psychologists. ${ }^{17}$

At its inception, the project was primarily concerned with European standards, but the locus of reform quickly shifted to Asia, the Middle East, and Latin America. Instead of remodeling French and Italian departmental structures, the project directors held a series of regional roundtables - each chaired by a European - in South Asia, the Middle East, and Latin America. National representatives compared their inadequate systems to the models described in the surveys of Europe and America in order to devise recommendations to submit to their own governments. Twenty "underdeveloped" states submitted requests for technical assistance to modernize their teaching (Unesco, 1954b). For a department that struggled to find a vocation in the regime of economic development, expanding social science education into the Third World was a welcome opportunity. The gaze of the SSD was now fixed on the periphery; a program begun as an effort to harmonize North Atlantic traditions and modernize Europe would be remembered twenty years later as "implanting the social sciences" in the Third World (de Franz, 1969).

Yet, as Meynaud later reflected, the change in focus came at a cost: "The need for ensuring a 'balanced' geographical representation - a need arising chiefly from the structure and policy of the institution responsible for financing the organizations concerned [i.e., Unesco]has led many international associations to admit to membership certain national bodies as to whose scientific qualifications they can cherish no illusions." Because the international associations paid "less attention to problems directly concerning the most advanced associations ... [the advanced associations] have not always perceived what practical advantage could accrue to them from the establishment of an International Association" (Meynaud, 1956, p. 9). When internationalization was scaled up from a transatlantic project to include Latin America, the Middle East, and Asia, the differences between North Atlantic nations became blurred; they were now identifiable as advanced.

In the newly independent nations, Unesco was clearly filling the vacuum left by the dissolution of colonial administrations, and it often drew on the same expertise. For instance, the SSD sent Dutch sociologist A. N. J. den Hollander to Indonesia in 1950 during the violent consolidation of independence to survey the state of the social sciences, assess the potential for technical assistance, and inquire into extending the international associations to the new nation. Not surprisingly, den Hollander reported a mixture of vague enthusiasm, disorganization, overwhelming material shortages (e.g., books), and pointed suspicion of a Dutch emissary ["Report on the Social Sciences in Indonesia," 1950, 3 (910) A 157, Unesco correspondence].

17. On the importance of international surveys for spreading categories, see Finnemore (1993). On IOs' role in the spread of categories more generally, see Barnett and Finnemore (2004), Boli and Thomas (1999). 
On top of these practical challenges, it remained to be seen whether non-Western intellectuals could be incorporated into a view from everywhere while maintaining the particular points of view that, in aggregate, promised a legitimately international perspective.

Efforts to internationalize disciplines were in constant tension with one of the core values of the view from everywhere: diversity. This often was not subtle. After participating in a seminar to train young social scientists from France, Sweden, Australia, and India to perform comparable community studies in their native countries, social psychologist Adam Curle wrote to Klineberg that although the Indians "seemed to understand the scientific points [he] was trying to make, they were in a peculiar way twisting them out of context to fit into a mode of thought which basically derived from an alien culture rather than from a shared scientific training" (Curle to Klineberg, 17 May 1949, 327.5: 301.18 A 53, Tensions Affecting International Understanding - Community Studies, Part I, Unesco correspondence files).

From the Asian perspective, the problem was that social science itself was a Western idiom. In a working paper on the use of textbooks at the Delhi Roundtable on the Teaching of Social Science, Irat Husain Zuberi, vice-chancellor of Rajshahi University in East Pakistan, wrote, "The main difficulty in translation of textbooks is that the Social Structure of countries in Asia is so different in many cases that the assumptions of Sociologists which are based on their observation of societies in Europe and America are not valid here." He continued, "Concepts in Western textbooks like 'City', 'Family' etc. do not assume the same significance for Eastern students as they would for a Social Scientist in the West." He concluded that there was an "urgent" need for "textbooks which are not a translation or adaptation of Western textbooks but are conceived and written by men belonging to Asiatic socio-economic and cultural life" (Zuberi, "Translation and Adaptation of Textbooks in the Social Sciences," ESCO 411005, Round Table Conference Re: Social Science Teaching in Universities and Secondary Schools, Delhi 15-20 February 1954, ILO Archive). A severe critique of the universality of Western social science, this argument also could support the rationale of the view from everywhere.

In fact, social scientists hoped internationalization would advance social science just as much as internationalized social science would advance the international community. International social science was vital to producing valid knowledge because it was expected to make genuine comparison possible. One of many calls for the formation of an International Institute of the Social Sciences declared, "The comparative method may well do for the social sciences what controlled experiment has done for the natural sciences." This optimism regarding the potential of comparative studies to reveal human nature and the laws of social behavior was tempered by warnings such as Wirth's to the First World Congress of Sociology that the comparative methods themselves did "violence to the [social] phenomena" by tearing them from "their peculiar historical, geographical, and situational contexts" (Anon., 1949b, p. 69; Wirth, 1951, p. 200). Despite Curle's exasperation, he encouraged the Indians to use their knowledge of Bengal as Bengalis to adapt psychological tests and the categories of social surveys to fit the local cultural milieu. By cultivating an international class of experts that could study phenomena in their native habitat and in their own terms, social science would develop a richer repertoire of more authentic cases, and perhaps from these develop a truly comparative method.

In the logic of the view from everywhere, an expert's capacity to legitimately represent a community was based in part on his or her membership in that community. For programs coordinated by an agency that represented member states, this community was, on first cut, defined by the nation. The U.N.'s federal model of international organization coincided with 
and was predicated on the spread and strengthening of nation states. ${ }^{18}$ But the degree to which states truly represented nations in the U.N. varied tremendously; in important respects, IGOs may be profoundly undemocratic institutions. Similarly, social scientists could never truly represent their national cultures. When the concept of cultural patterns had been elaborated in the interwar period, it was conventional practice to note that multi-class societies (i.e., industrial nations) could not be identified by a single cultural pattern. Indeed, access to an integrated, coherent cultural pattern was a justification for ethnographic studies of "primitive" societies. Before the war these cautions were often ignored in practice, and the need for national unity in a conflict between nations further eroded the qualifications. ${ }^{19}$ But the warnings were on point. Beyond the deeply problematic reification of a national character (Igo, 2007), the argument can be extended to ever smaller social scales. Did the Bengali elites Curle trained speak more authentically for their research subjects - low-caste squatter refugees from postpartition violence in East Pakistan - than Gujarati or Swedish researchers could?

The pursuit of the view from everywhere outside the North Atlantic exposed the tension between spreading a disciplined way of knowing and representing the diversity of worldviews. But this very tension was what might make possible the cultivation of experts who could represent the international community.

\section{THE IdEAL OF Two-WAy TRAFFiC}

Ultimately, an objective view of social phenomena could be obtained only by synthesizing the perspectives of observers who had been molded by diverse national cultures. An International Political Science Association statement justifying its own existence explained that "students of politics combine fact-finding with value judgment" and "every scholar takes his problems and guiding concepts from his own environment." It continued, "Frequent contacts between political scientists of different countries would stimulate awareness of these factors," thus allowing scholars to "distinguish between the analysis of verifiable facts and the formulation of value judgments" (Ebenstein, 1948, p. 1186). International collaboration, in other words, would enhance scholars' reflexivity. More ambitiously, a Society for the Psychological Study of Social Issues proposal for an international institute described how the process of international collaborative research was a means of "transcending [the] disparity of cultural perspectives" (SPSSI, 1950, p. 81). An International Sociological Association report emphasized the "the unique opportunity implied in [Unesco's] supra-national position" to "contribute in a decisive way ... to the promotion of attitudes of international loyalty among social scientists" (ISA, 1953). Whereas national patrons cultivated social scientists' patriotic loyalties, an international organization could develop a cadre of experts whose international loyalties produced an intercultural perspective. This was the ideal of the view from everywhere that the SSD strove to coordinate.

18. On the postwar transformation from an imperial to an international world order, see Cooper (2005), Jackson (1990), and Tilly (1992). I follow Tilly's practice of not hyphenating "nation state" in order not to conflate nations and states. The spread and the strengthening of nation states must be understood separately because many of the new states proved to be so weak that they only possessed a sort of "quasi" sovereignty — one based on international recognition rather than effective power-while the postwar sovereign authority and control of governments in developed nations certainly was unprecedented. For a compelling refutation of the myth of the decline of the nation state, see Smith, Salinger, and Topik (1999).

19. Ruth Benedict stressed the multicultural character of industrialized countries in her popular and extremely influential Patterns of Culture, but, like other scholars, easily slipped into descriptions of the American cultural pattern: Babbitt as the archetypical man, Middletown as the archetypical community (Benedict, 1959; Lynd \& Lynd, 1929). 
Some sense of social scientists' commitment to the value of international patronage can be seen in the energetic lobbying of Alva Myrdal. On a junket in the U.S. to gain support for the Institute, she wrote to the director-general that she deliberately ignored suggestions to seek foundation support. This was because of her "very strong conviction-a kind of 'Unesco pride' - that only if and when we are assured of government support for the centre would the time be opportune to seek outside financial aid." She reported that Margaret Mead had advised her that "inter-personal and inter-group relations" as they related to "war and peace" were the "Leitmotif of the Ford Foundation" and support for the international institute might be possible under its new initiative in the "behavioural sciences." But "a gift from this Foundation ... would make the centre theirs rather than Unesco's, and American rather than international" [Myrdal to Director-General, 8 October 1951, 3 A 01 ISSC-66, International Social Science Council, Part I (d), Unesco correspondence]. Ironically, while the Central Intelligence Agency secretly supported the purportedly non-governmental Congress for Cultural Freedom and laundered funds for psychological research through foundations, for an IGO money from the U.S. government was actually less tainted by its American origins (Lemov, 2005; Saunders, 1999). ${ }^{20}$ Although Unesco's program in the internationalization of social science could seem like Americanization, for Myrdal and her colleagues, it was a way of internationalizing American resources.

For Myrdal, the essential contrast between the American and Unesco approach was the mode of cooperation. In a mission report on a 1953 trip to India to "consult governmental authorities and scientific experts" on plans to establish a research institute on "the human and social implications of technological change," Myrdal confronted the problem of the overwhelming scale of U.S. initiatives. She reported that the U.S. government was investing \$50 million and the Ford Foundation $\$ 6$ million in community development schemes, while Unesco's entire budget for 1953 was $\$ 9$ million and the SSD's \$540,642 - the American expert the SSD hired to test the waters for the new institute worked with an $\$ 8,000$ budget. This only made the proposed institute more vital because "an international institute, providing for systematic comparisons and also for stimulating co-operation of an international staff, would be very different from the one-way traffic of cultural influence, which remains typical of the Ford enterprise" (Myrdal to Director-General, 4 February 1953, X07.83, Myrdal, Unesco correspondence). For the SSD, technical assistance should broaden the perspective of the international communityalter the terms in which development was measured and influence the attitudes of international experts - as much as provide the technological base for economic take off.

This faith in cross-cultural collaboration was the leitmotif of Unesco. In an article titled "Technical Assistance: A Two-Way Traffic," in the agency's popular journal the Unesco Courier, American author and public intellectual Pearl S. Buck wrote, "In the contact that is now inevitable between the peoples of Occident and Orient the greatest change will come in the Occident. It will not be so visible, at first, as the change in the Orient. A refrigerator is a monstrously visible thing, but the change in a man's attitude toward life is far more important and powerful" (Buck, 1950, p. 5). In a report to the Director-General, Angell expressed his hope that U.S. engagement in Unesco's development program would adjust American values: "If the American people could be led to see their responsibility to the world as similar to the responsibility which certain American states have taken toward the rest, this might produce a more constructive attitude toward the U.S. role in the world" (Angell to Director-General,

20. Unable to win government support for an international social science institute, the SSD had to settle for the International Social Science Council, yet another impoverished coordinating body, its offices inside Unesco House were a physical testimony to its status as a wheel within a wheel. 
24 April 1950, 327.6: 3 A 06, Meeting of Social Scientists on "The Role of Social Scientists in World Affairs," Unesco correspondence). Despite the antinationalist spirit of the SSD's mission, for the American social scientists who participated in its programs - among the trendsetters in their fields, including the quintessentially Cold War behavioral sciencesloyalty to the United States and to the international community was not contradictory, and both involved tempering American power with international understanding. ${ }^{21}$

Unesco did not have a monopoly on the ideal of the two-way street. In fact, as Nicole Sackley has shown, the experts advising the American-sponsored Indian community development schemes that Myrdal dismissed as mere "one-way cultural traffic" echoed many of the values she and Buck articulated. The SSD advised University of Chicago anthropologist Milton Singer on his and Robert Redfield's "Comparative Civilizations" project, which had objectives and methods that closely resembled much of the Department's own early program (Sackley, 2004; Martin to Singer, 12 December 1951, 327.5: 301.18 A 53, Tensions Affecting International Understanding - Community Studies, Part II, from 1/XI/49). And when John D. Rockefeller III visited Japan in 1951 to advise the U.S. Department of State on cultural relations policy, he made the "concept of the two-way street" the centerpiece of the report. $\mathrm{He}$ warned against cultural "imperialism," which "would in the long run be as unfortunate for ourselves as Japan" (Matsuda, 2007, p. 104). Indeed, from elementary school pen pals to graduate school area studies programs, a "cosmopolitan agenda ... would guide American postwar thought" (Engerman, 2007, p. 610). While more than "Unesco pride" justified Myrdal's claim that traffic flow was more balanced in the U.N. agency's programs, what is significant here is that the ideal was part of mainstream thinking.

The theme of two-way traffic extended all the way down to the recruitment of experts for technical assistance missions. Guidelines for selecting experts emphasized that "objective measurements can never replace personal valuation based on observation" because "even an impressive paper record of degrees and experience gives little data about the personal attitudes which often have as much to do with an expert's success as professional competence." The ideal expert should "have humility, patience and adaptability unrelated to specialized abilities," and be "willing to learn as well as teach" ("Informational Meeting on Recruitment of Technical Assistance Specialists,” 20 November 1952, X07.2 TA/A 131, Technical Assistance Recruitment Policy, Unesco correspondence). Such considerations appear obvious, but the emphasis on character over expertise is far from the image of the interchangeable technical expert who was just "expected to follow rules" (Porter, 1995, p. 195).

The Technical Assistance Department guidelines doubted that character could be taught, but the SSD did engage in bureaucratic therapy in its International Collaboration Project. Directed by Sharp (whose "Progress Report" on the specialized agencies fretted over "wheels within wheels"), the project's objective was to "encourage and assist the study by social scientists in all Member States of the problems arising within their respective scientific fields in relation to the contemporary development of positive international collaboration" (Unesco, 1948b, p. 453). Sharp was a veteran of FAO, WHO, and UNRRA, so he knew well the challenge he was taking on.

The most important element of this project was a rather bland-sounding study of the "technique of international conferences." In fact, it was seen as breaking ground in a "pioneer

21. The metaphor of expanding circles of loyalty beginning with the family and, as an individual matured, enlarging to include ever larger communities (school, neighborhood, town, state, nation, and finally, in a better future, the world community) was fundamental to internationalist social scientists. For one of countless statements, see Lasswell (1948). For an exemplary study of scientists' ability to balance national and international commitments, see Needell (2000). 
field" that promised methodological innovation, theoretical insight, and practical application. It required an interdisciplinary research team led by a political scientist and social psychologist in consultation with cultural anthropologists, psychiatrists, jurists, and international officials to probe the "group dynamics" of "this involved area of human relations" (Unesco, 1951, p. vi). To coordinate this ambitious study of the factors that determined a conference's success, Sharp tapped the resources of the emerging international social science community. He toured Scandinavia, visited the WHO and U.N. offices in Geneva, and stopped off in Brussels before heading to London. There, a conversation with Dr. Elliot Jaques of the Tavistock Institute of Human Relations (the U.K. distributor of the Society for the Psychological Study of Social Issues' Journal of Social Issues) was particularly productive. Jaques suggested holding a "conference on conference method" that "with the advice of a team of social psychologists, [would] undertake to study itself-as a 'guinea pig' situation" ("Report on Visit to London 8-11 Sep. 1948," (100) A 81/6, Social Sciences-International Collaboration Project, Unesco correspondence).

Solipsistic as this proposal might seem, it was not an anomaly. In 1950, psychiatrist John Rickman suggested Unesco sponsor "a conference of what happens in the conference itself," even at the risk that this would "wreck" the conference-and perhaps the organization (Rickman to Angell, 15 May 1950, 327.6: 3 A 06, Meeting of Social Scientists on "The Role of Social Scientists in World Affairs," Unesco correspondence). The reflexive stance of these proposals reflected the conference study's therapeutic approach to transforming the dynamics of human relations. The study was based on the assumption that conferences represented microcultures that patterned human behavior. Transforming these cultures, therefore, could cultivate more open-minded, rational personalities capable of constructive interpersonal relations. In this theory of social reform, it was those with power who most required therapy; they determined whose point of view was represented.

After these meetings with European social scientists, and similar meetings in the United States, conferences of experts in Paris and New York developed a "systematic plan" of research. Small teams of experts would perform action-research in the field to observe "in depth" the "pathology" of conferences. "Participant-observers" would "participate freely" in the planning of conferences in order to understand each meeting within its peculiar "life history." They would "feed back" their findings to the conference both to improve the chances for its success and, by changing the experimental situation, evaluate hypotheses. At a basic science level, such studies were grounded in and could contribute to the psychological theory of group dynamics. Pilot studies were made at meetings of the U.N. Human Rights Commission, the Economic Commission for Europe, and at the WHO General Conference (Sharp, 1950; Unesco, 1951). ${ }^{22}$

The research program for improving international collaboration resembled group therapy, but for Sharp, a political scientist, this was not a retreat to psychology, but rather an embrace of it. In a "Memorandum of instructions" to his assistant early in the project, he wrote, "In my opinion, the psychological aspect of the problem should receive major emphasis in the proposed study" (Sharp to Godchot, 30 October 1948, (100) A 81/6, Social SciencesInternational Collaboration Project, Unesco correspondence; emphasis in original). Rensis Likert, director of the University of Michigan Institute for Social Research, traveled to Paris with plans for an intensive social survey of Unesco in order to improve morale and efficiency (Angell to Herring, 17 November 1949, 327.5: 301.18 A 53, Tensions Affecting International

22. The research also tackled mundane problems such as the best practices for translation and when and how much documentation to distribute. For contemporary accounts of the practices represented in this study, see two issues of The Journal of Social Issues (Society for the Psychological Study of Social Issues, 1945 and 1947). 
Understanding - Community Studies, Part II, Unesco correspondence). Charles Ascher, a U.S. authority on public administration who acted as a "participant-observer" while Executive Officer for the Program, ended his study of program making in the organization-which included descriptions of the office layout of Unesco House in the Hotel Majestic, biographies of key leaders, analysis of changes in organizational structure, and blow-by-blow summaries of board meetings - with a plea that only by developing the quality of "selflessness" in the agency's leadership could it devise a work plan that would evoke "loyalty not only within the Secretariat but throughout the world" (Ascher, 1951, p. 84). Although particularly pronounced at Unesco with its mandate to intervene in "the minds of men," the conviction that action-research could improve the international bureaucracy by improving international bureaucrats was widespread. Representatives of the Carnegie Endowment, Ford Foundation, Rockefeller Foundation, and Centre National de la Recherche Scientifique were interested enough to participate in a three day meeting to evaluate the project's findings (Unesco, 1952). ${ }^{23}$

These studies may appear quaintly myopic given the power of factors external to IGOs to determine an organization's success. Yet Brock Chisholm, the psychiatrist director-general of WHO, speculated that if the pilot studies were developed into a long-term research program, they "might well be recognized by future generations as the most important research begun in this century." For Chisholm, the studies "demonstrated that social science participation through an action-research approach can strengthen the more mature world-minded attitudes" (Chisholm, 1953, pp. 235-236). This work was conducted by experts who believed in the potential of international cooperation; to assume the experiment's inefficacy was to assume the failure of the United Nations. Only diplomats who negotiated in good faith and civil servants who worked with integrity could collaborate productively. Only experts capable of intercultural collaboration were in a position to provide the knowledge on which a world community depended. The action of social research was intended to change the attitudes of both experimenters and subjects. Group therapy was a method of institutional reform. Its goal was to produce representatives loyal to the world community.

\section{CONCLUSION}

If the U.N. was the institutional embryo of a liberal democratic world polity, there was little doubt that the gestation would be measured in human generations. The task of international experts was to build the circulatory system that would enable the threatened embryo to grow: Power and knowledge would flow through arteries and veins that connected U.N. organizations to capillary networks within nations to nurture the world community. The impossibility of the metaphor - an embryo feeding its womb - is apt. But this is the central problem of institutionally based social reform: to create an institution that functions in a world it is meant to transform.

INGOs were both a means and an end because they were a way to provide the world community with an international perspective from which to determine goals and evaluate policy options. At the same time, they fostered cosmopolitan intellectuals whose identification with a transnational group superimposed loyalty to the international community on national loyalties. The federal model of the international associations mimicked and emerged out of the liberal

23. In particular, the Carnegie Endowment for International Peace supported many analogous programs. In addition to studies of conferences, the Endowment produced the National Studies of International Organization series, which mirrors on a much larger scale another International Collaboration Project endeavor. Howard E. Wilson, the Endowment's assistant director for education, was deputy director of the Unesco Preparatory Commission, and the Endowment seconded him to Unesco to direct the first major seminar for educators in its Education for International Understanding program. 
democratic political structures of the U.N. It was based on the conviction that representative government required representative knowledge production.

In this vision, truth emerged from the process of international collaboration. Unesco's function was to coordinate the perspectives of intellectuals who represented national cultures in order to construct a synoptic view of the world community, and thus provide the knowledge necessary to integrate diversity in an interdependent world. Coordinating the view from everywhere was a demanding practice, especially since the representatives of the international community were also products of their national cultures. Social scientists were keenly aware of this dilemma. They believed the success of institutions depended on the personalities who carried out their functions. Unesco policy emphasized the character of international experts and civil servants, and the SSD performed action-research to enhance their intersubjective faculties. In this mode of research, the boundary between participant and observer was intentionally blurred, and the experiment was group therapy as a form of social reform. Researchers hoped to cultivate new values appropriate for a world community through the experience of international collaboration. In the absence of a mature world community, no individual could see the view from everywhere; it emerged only out of cooperative interpersonal relations.

With the rise of development as the overriding mission of the specialized agencies, the SSD's program in international collaboration morphed from a project aimed at harmonizing North Atlantic cultural relations to developing the social sciences in the Third World. Because the normative ethos of technical assistance was tutoring underdeveloped countries in order to accelerate their evolution into industrialized nation states - the one-way traffic Myrdal complained of - it is easy to miss the essential point of how much of the flurry of postwar international organizing was designed to manage the problem of power, particularly American hegemony, in a democratic world order. American resources and initiative fueled the international institutionalization of the social sciences, but Europeans guided its progress. Almost as soon as they were formed, transnational associations followed the economic development missions of the specialized agencies into the Third World; the rationale was to share the power of knowledge production in order to avoid an imperial perspective.

Sixty years later, the notion of a world state has lost its allure. Yet if Unesco's attempt to find unity in diversity did not produce the world community in which such a state would make sense, it did change Unesco. Decolonization transformed the SSD; during the second half of the 1950s and the 1960s, the department struggled to maintain its prestige and attract highcaliber experts, but its conferences, publications, and projects increasingly represented the work of scholars from outside social sciences' indigenous homeland in the North Atlantic. For better and worse, the Department's perspective came closer to approximating a view from everywhere. Objectivity is always a matter of degree. Just because it, like world peace, was an impossible ideal, does not mean it was not worth pursuing. The pursuit was half the point.

\section{ACKNOWLEDGMENTS}

I would like to thank Sarah Igo, Susan Lindee, Joy Rohde, Damon Yarnell, and two anonymous reviewers for their constructive criticism and encouragement.

\section{REFERENCES}

\section{Archival References}

Correspondence files, Unesco Archive, Paris, France.

International Labor Organization Archive, Geneva, Switzerland. 


\section{Printed References}

Anon. (1949a). Unesco and the social sciences. International Social Science Bulletin, 1, 9-10.

Anon. (1949b). Draft proposals for the establishment of an International Institute of the Social Sciences. International Social Science Bulletin, 1, 68-71.

Anon. (1951a). The meeting of the secretaries of international social science associations. International Social Science Bulletin, 3, 116-118.

Anon. (1951b). The co-ordinating committee for social science documentation. International Social Science Bulletin, 3, 118-121.

Anon. (1951c). The work of the International Economic Association. International Social Science Bulletin 3, 851-855.

Anon. (1953). The enquiry into the teaching of the social sciences: General report submitted to Unesco's General Conference, 1952. International Social Science Bulletin, 5, 151-157.

Ascher, C. (1951). Program-making in Unesco, 1946-1951. Chicago: Public Administration Clearing House.

Ash, M. G. (1992). Cultural contexts and scientific change in psychology. American Psychologist, 47, $198-207$.

Ash, M. G. (1995). Gestalt psychology in German culture, 1890-1967: Holism and the quest for objectivity. Cambridge: Cambridge University Press.

Barnett, M., \& Finnemore, M. (2004). Rules for the world: International organizations in global politics. Ithaca: Cornell University Press.

Benedict, R. (1959 [1934]). Patterns of culture. Boston: Houghton Mifflin Co.

Boli, J., \& Thomas, G. (Eds.). (1999). Constructing world culture: International Nongovernmental Organizations since 1875. Stanford: Stanford University Press.

Buck, P. S. (1950). Technical assistance: A two-way traffic. Unesco Courier, 5.

Carson, C. (2003). Objectivity and the scientist: Heisenberg rethinks. Science in Context, 16, 243-269.

Chisholm, B. (1953). Preface. International Social Science Bulletin: The Technique of International Conferences, 5, 233-237.

Clark, T. N. (1973). Prophets and patrons: The French university and the emergence of the social sciences. Cambridge, MA: Harvard University Press.

Coakley, J., \& Trent, J. (2000). History of the International Political Science Association, 1949-1999. Dublin: IPSA.

Cohen-Cole, J. (2004). Thinking about thinking in Cold War America. Ph.D. dissertation, Princeton University.

Connelly, M. (2000). Taking off the Cold War lens: Visions of North-South conflict during the Algerian War for Independence. American Historical Review, 105, 739-770.

Connelly, M. (2006). Seeing beyond the state: The population control movement and the problem of sovereignty. Past and Present, 193, 197-233.

Converse, J. M. (1987). Survey research in the United States: Roots and emergence. Berkeley: University of California Press.

Cooper, F. (2005). Colonialism in question: Theory, knowledge, history. Berkeley: University of California Press.

Coser, L. (1984). Refugee scholars in America: Their impact and their experiences. New Haven: Yale University Press.

Daston, L. (1992). Objectivity and the escape from perspective. Social Studies of Science, 22, 597-618.

Daston, L., \& Galison, P. (2007). Objectivity. New York: Zone Books.

de Bie, P., Lévi-Strauss, C., Nuttin, J., \& Jacobson, E. (1954). The teaching of the social sciences: Sociology, social psychology and anthropology. Paris: Unesco.

de Franz, M. A. (1969). Implanting the social sciences: A review of Unesco's endeavours. International Social Science Bulletin: Social Sciences in the Third World, 21, 406-420.

Ebenstein, W. (1948). Toward international collaboration in political science: A report on the Unesco project, "Methods in political science." American Political Science Review, 42, 1181-1189.

Engerman, D. C. (2007). Bernath lecture: American knowledge and global power. Diplomatic History, 31, $599-622$.

Fawtier, R. (1949). Is a world council of philosophy really necessary? Unesco Courier, 22, 2.

Finnemore, M. (1993). International organizations as teachers of norms: The United Nations Educational, Scientific, and Cultural Organization and science policy. International Organization, 47, 565-597.

Gilman, N. (2003). Mandarins of the future: Modernization theory in Cold War America. Baltimore: Johns Hopkins University Press.

Goldman, M. (2007). How "water for all!" became hegemonic: The power of the World Bank and its transnational policy networks. Geoforum, 38, 768-800.

Graham, S. E. (2006, April). The (real)politiks of culture: U.S. cultural diplomacy in Unesco, 1946-1954. Diplomatic History, 30, 231-251.

Greenway, F. (1996). Science international: A history of the International Council of Scientific Unions. Cambridge, UK: Cambridge University Press.

Haas, P. (Ed.). (1992). Knowledge, power, and international policy coordination. International Organization, 46, 1.

Harris, B., \& Nicholson, I. (Eds.). (1998). Experts in the service of social reform: SPSSI, psychology, and society 1936-1996. Journal of Social Issues, 54, 1.

Herman, E. (1995). The romance of American psychology: Political culture in the age of experts. Berkeley: University of California Press. 
Hollinger, D. (1995a). Postethnic America. New York: Basic Books.

Hollinger, D. (1995b). Science as a weapon in kulturkampfe in the United States during and after World War II. Isis, $86,440-454$.

Igo, S. (2007). The averaged American: Surveys, citizens, and the making of a mass public. Cambridge, MA: Harvard University Press.

Ikenberry, G. J. (2001). After victory: Institutions, strategic restraint, and the rebuilding of order after major wars. Princeton, NJ: Princeton University Press.

Iriye, A. (2002). Global community: The role of international organizations in the making of the modern world. Berkeley: University of California Press.

International Sociological Association (ISA). (1953, July 31). Notes toward a tentative evaluation of current research in the field of sociology. Paris: Unesco.

International Social Science Council (ISSC). (1954). Report of the secretary general for the year 1952-53 to the General Assembly. Paris: Unesco.

Jackson, R. (1990). Quasi-states, sovereignty, international relations and the Third World. Cambridge, UK: Cambridge University Press.

Jolly, R., Emmerij, L., Ghai, D., \& Lapeyre, F. (2004). U.N. contributions to development thinking and practice. Bloomington: Indiana University Press.

Judt, T. (1992). Past imperfect: French intellectuals, 1944-1956. Berkeley: University of California Press.

Keck, M., \& Skikkink, K. (1998). Activists beyond borders: Advocacy networks in international politics. Ithaca, NY: Cornell University Press.

Khagram, S. (2004). Dams and development: Transnational struggles for water and power. Ithaca, NY: Cornell University Press.

Kohler, R. E. (1990). The Ph.D. machine: Building on the collegiate base. Isis, 81, 638-662.

Krige, J. (2006). American hegemony and the postwar reconstruction of science in Europe. Cambridge, Mass.: MIT Press.

Krohn, C. D. (1993). Intellectuals in exile: Refugee scholars and the New School for Social Research. Amherst: University of Massachusetts Press.

Lasswell, H. D. (1948). World loyalty. In Quincy Wright (Ed.), The world community (pp. 200-225). Chicago: The University of Chicago Press.

Lemov, R. M. (2005). World as laboratory: Experiments with mice, mazes, and men. New York: Hill and Wang.

London Times. (1957, July 1). In Weekly Press Review (12 July 1957). Paris: Unesco.

Lynd, R. S., \& Lynd, H. (1929). Middletown: A study in American culture. New York: Harcourt, Brace and Company.

Mann, T. (1997 [1947]). Doctor Faustus: The life of the German composer Adrian Leverkun as told by a friend. New York: Vintage Books.

Matsuda, T. (2007). Soft power and its perils: U.S. cultural policy in early postwar Japan and permanent dependency. Stanford, CA: Stanford University Press.

Megill, A. (Ed.). (1994). Rethinking objectivity. Durham: Duke University Press.

Mendelsohn, E. (1989, Spring). Robert K. Merton: The celebration and defense of science. Science in Context, 3 , 269-289.

Meynaud, J. (1956). International organizations in the social sciences: A summary description of the structure and activities of non-governmental organizations in consultative relationship with Unesco and specialized in the social sciences. Reports and Papers in the Social Sciences, 5. Paris: Unesco.

Murphy, G. (Ed.). (1945). Human nature and enduring peace: Third yearbook of the Society for the Psychological Study of Social Issues. Boston: Houghton Mifflin Co.

Nagel, T. (1986). The view from nowhere. Oxford: Oxford University Press.

Needell, A. (2000). Science, Cold War and the American state: Lloyd V. Berkner and the balance of professional ideals. Amsterdam: Harwood Academic Publishers.

Ninkovich, F. (1981). The diplomacy of ideas: U.S. foreign policy and cultural relations, 1938-1950. Cambridge, UK: Cambridge University Press.

Nolan, J., Jr. (1998). The therapeutic state: Justifying government at century's end. New York: New York University Press.

Pells, R. (1997). Not like us: How Europeans have loved, hated, and transformed American culture since World War II. New York: Basic Books.

Petijean, P. (2006). Blazing the trail: Needham and UNESCO: Perspectives and realizations. In J. Lamar (Ed.), Sixty years of science at UNESCO, 1945-2005 (pp. 43-47). Paris: Unesco Publishing.

Platt, J. (1998). A brief history of the ISA, 1948-1997. Montreal: ISA.

Platt, J. (2003). The British Sociological Association: A Sociological History. Durham, UK: Routledge-Cavendish.

Porter, T. (1995). Trust in numbers: The pursuit of objectivity in science and public life. Princeton, NJ: Princeton University Press.

Rist, G. (1997). The history of development: From Western origins to global faith. London and New York: Zed Books.

Robin, R. (2001). The making of the Cold War enemy: Culture and politics in the military-intellectual complex. Princeton, NJ: Princeton University Press.

Rodgers, D. (1998). Atlantic crossings: Social politics in a progressive age. Cambridge, MA: Harvard University Press. 
Sackley, N. (2004). Passage to modernity: American social scientists, India, and the pursuit of development, 1945-1961. Ph.D. dissertation, Princeton University.

Saunders, F. S. (1999). Who paid the piper? The CIA and the cultural cold war. London: Granta.

Scott-Smith, G., \& Krabbendam, H. (2003). The cultural cold war in Western Europe, 1945-1960, London: F. Cass.

Sewell, J. P. (1975). Unesco and world politics: Engaging in international relations. Princeton, NJ: Princeton University Press.

Shapin, S. (1994). A social history of truth. Chicago: University of Chicago Press.

Sharp, W. R. (1947). The specialized agencies and the United Nations: Progress report I. International Organization, 1, 460-474.

Sharp, W. R. (1950). The scientific study of international conferences. International Social Science Bulletin, 2, 104-116.

Smith, D., Salinger, D., \& Topik, S. (Eds.). (1999). States and sovereignty in the global economy. London and New York: Routledge.

Society for the Psychological Study of Social Issues (SPSSI). (1945). The psychological problems of bureaucracy. Journal of Social Issues, 4.

Society for the Psychological Study of Social Issues (SPSSI). (1947). Action and research: A challenge. Journal of Social Issues, 2.

Society for the Psychological Study of Social Issues (SPSSI). (May 1950). Proposal for the establishment of a United Nations Institute for the Human Sciences. In Economic and Social Council (Ed.), Report of the committee of scientific experts on international research laboratories (pp. 78-104). Paris: Unesco.

Stocking, G., Jr. (Ed.). (1986). Malinowski, Rivers, Benedict and others: Essays on culture and personality. Madison: University of Wisconsin Press.

Tilly, C. (1992). Coercion, capital, and European states, AD 990-1992. Cambridge, MA: Blackwell.

Unesco. (1948a). Resolutions adopted by the General Conference during Its Second Session, Mexico, Nov.-Dec. 1947. Paris: Unesco.

Unesco. (1948b). Records of the General Conference of the United Nations Educational, Scientific and Cultural Organization: Second session, Mexico, 1947, Vol. 1: Proceedings. Paris: Unesco.

Unesco. (1950a). Report of the director general on the activities of the organization from October 1949 to March 1950. Paris: Unesco.

Unesco. (1950b). Contemporary political science: A survey of methods, research and teaching. Paris: Unesco.

Unesco. (1950c). Meeting of secretaries of the international social science associations. Paris: Unesco.

Unesco. (1951). The technique of international conferences: A progress report on research problems and methods. Paris: Unesco.

Unesco. (1952, March). Meeting of experts on the technique of international conferences, 22-24 Oct. 1951. Paris: Unesco.

Unesco. (1953). The teaching of the social sciences in the United Kingdom. Paris: Unesco.

Unesco. (1954a). The teaching of the social sciences in the United States. Paris: Unesco.

Unesco. (1954b). Development of social science teaching: Progress report and analysis of regional round tables. Paris: Unesco.

Unesco (1955, March 28). Meeting of representatives of national social science councils and similar bodies-Paris, 14-17 Dec. 1954. Paris: Unesco.

Unesco. (1956). Meeting of experts on social science terminology, 22-24 May 1956. Paris: Unesco.

Wirth, L. (1951). The significance of sociology: Opening adres [sic] of the World Congress of Sociology. International Social Science Bulletin, 3, 197-202.

Worcester, K. (2001). Social Science Research Council, 1923-1998. New York: Social Science Research Council. 